\section{Enhancing the Employability of \\ Leisure Studies Graduates through Work Integrated Learning}

\author{
Kevin D. Lyons, University of Newcastle, Australia \\ and \\ Peter Brown, Griffith University, Australia
}

\section{Abstract}

Graduate employment rates are often used in Australian universities as a key performance indicator in relation to teaching and learning outcomes. While ieisure studies and related curricula have always concerned themselves with preparing students for careers within the broadly-based leisure industries, given the climate of funding of higher education, such programs may be vulnerable uniess they can demonstrate their professional reievance. This paper examines how incorporating a student-centred whole-life approach to career development into lessure studies curricula can enhance graduate employability, as a key performance outcome. The framework for this examination is provided through a casestudy of a Work Integrated Learning (WIL) initiatıve deveioped in the Bachelor of Socia Scrence (Recreation and Tourism) program at the University of Newcastie, Australia. While this paper focuses on the Australian context, many of the issues relating to career development and planning are likely to apply to other countries, since many of the changes relating to careers are a direct result of the giobalization of business activity.

\section{Introduction}

Graduate outcomes are a critical indicator of how effectively unıversities are defining and instilling the skills and attributes expected of their graduates, with success in the labour market being the most obvious indicator of satisfactory outcomes. - Dept of Education, Training \& Youth Affairs (1999:15)

These comments, from a recent Australian Commonwealth government report, are indicative of a trend towards greater leveis of public accountability in relation to the delivery of educational outcomes in Australia. Universities, in particuiar, are under growing pressure to account for their performance, not oniy in terms of financial viability or the numbers of students 'through the door', but also in terms of the amount of 'value adding' that takes place, from when students first enroll in a degree program to when they graduate (Evers, Rush, \& Berdrow, 1998). One such area of 'value adding', and a key outcome measure of university performance, is graduate employability and the extent to which graduates' attributes are deemed to be relevant to the labour market (Buck \& Barrick, 1987). Increasingly, results from employer satisfaction and graduate destunation surveys (Dept of Education, Training \& Youth Affairs, 1998; Johnson, 1998) are being used as indicators of performance. It is important to note that, while performance assessment and accountability has existed in universities for decades, recent emphasis has been placed upon using these indicators as points of comparison between higher education institutions at a national level. The formation, in 2001, of the Australian Universities Quality Agency (AUQA), and its recent policy statements, suggest that such indicators will be used in the future to inform funding allocations within the Australian higher education system. If graduate employability is a measure of the success of undergraduate education programs then it is important to consider how tertiary institutions might best respond to the challenge of preparing graduates for future careers and a world of work that has changed radically in the last two decades.

In 1984, British writer Charles Handy foreshadowed a range of factors that he believed would lead to dramatıc changes in the way work is structured and experienced. His predictions have proved accurate: at the start of the new millennium economic changes, new technology and globalized business practices continue to have a profound effect on career structures and chorces. The net effect of these changes is a widening diversity of career patterns and experiences in which workers are increasingly choosing, or being forced to pursue, what Handy (1984, 1996) termed 'portfolio careers'. The idea of a portfolio career - deveioped later in this paper - is a useful one for framing a discussion about work patterns and worker experiences and the role of learning institutions in assisting individuals to prepare for a work envuronment characterized by fragmentation, uncertainty and change.

Drawing on concepts and theories from contemporary literature on career development and career planning, the main aum of this paper is to examune how lessure studies and related programs might incorporate into curricula specific strategies that not only enhance the employability of students on graduation but also equip graduates with career-planning skills for life. In relation to this am, three key questions are addressed in this paper: 1 . What strategies are currently used in undergraduate programs to assist students with career plannung? 2. What more could be done to equip students with lifelong skills and to evaluate their skills and knowledge in reiation to future career options and choices? What evidence might graduates use to highlight their capabilities in relation to different employment roles?

These questions are examined in two ways. The first part of the paper provides some background to the higher education system in Australia and the origns of Teisure studies programs in unversities, to highlight the importance of graduate employability as a key outcome measure of performance in relation to teaching and iearning. Consideration is then given to current university practices relating to strategies for supporting students in developing career planning skills. The second half of the paper outlines how a whole-life approach to career development (including work placements and student portfolios) was impiemented through a 
Work Integrated Learning (WIL) initiative in the Bachelor of Soctal Science (Recreation and Tourism) program at the University of Newcastle. This case-study offers one response to the challenge of adding value to student capabilities, in a world where globalized business activity is changing patterns of work and influencing career options and choices.

\section{Background}

Letsure and recreation studies programs are now well-established in Australia with undergraduate and postgraduate degree courses being offered in 15 of the country's 37 public universities. The origins of many of these programs can be traced back to the recreation and physical education trauning programs offered through the former College of Advanced Education (CAE) and Tertiary and Further Education (TAFE) systems in the 1970s. These courses were unashamedly vocational in nature, were developed in consultation with employers and other stakeholders, and aimed to prepare professionais to work in operational and management positions in the burgeonung lessure industries (Lynch \& Jonson, 1999). While leisure studies programs now contain more academically rigorous and theoretically rich material than their predecessors, there is a continued claim that the main purpose of these programs is to provide students with the skills and knowledge necessary for employment in organisations in the leisure field. This clam is evident in the following extracts taken from promotional material from three universities with prominent undergraduate programs in leisure studies:

This course provides students with the knowledge and professional skills necessary to operate within the leisure industry. (University of Technology Sydney, 2001: 1)

This degree provides students with the knowledge and skills for professionai careers in the recreation and toursm industries. (University of Newcastie, 2001: 1)

This degree course prepares professtonal leisure service managers for potentıal careers in service delivery and management in the recreation, sport and tourism undustries. (Griffith University, 2001: 1)

If, as these examples of promotional literature suggest, the main aim of undergraduate leisure studies programs is to prepare students for careers in the broadlybased lessure industries, how is the enhancement of graduate employability best achieved and how might performance be measured?

The first question has, to-date, been left to individual universities to work out in consultation with industry and other stakeholder representatives to ensure that regional industry needs are met through a particular program. However; this approach has often lead to highly specialized programs that may have lacked the transferability needed in contemporary work environments. In regard to the second question it is necessary at the outset to provide a brief overview of higher education in Australia, and the data that are currentiy used to evaluate university achievements
in relation to graduate outcomes.

The Australian higher education sector comprises, for the most part, autonomous, self-accrediting universities established under State, Territory or Commonwealth legislation. Australia's 37 public universities recerve operatung grant funding from the Commonwealth government on a triennual basis. Since 1998, such funding has been based on the submission of plans by each university outlining its mission and aims, the strategies to be used to achieve these aums, and the indicators and outcomes used to monitor the success and quality of what is being achieved in relation to: teaching and learning; research; communty service; and management. While the format and content of the pians are left to individual institutions, as a minumum requirement they are expected to include a description of graduate attributes, evidence of feedback from employers on the quality of gxaduates and data on employment of recent graduates and graduate perceptions of teaching quality. The last two indicators, which are derived from the Graduate Careers Council's Course Experience Questionnatre and Graduate Destination Survey (see Johnson, 1998) which is sent to all graduating students each year, will play an important part in the AUQA's audit of universities (commencing in 2002) as well as subsequent decisions about funding allocations based on performance. Financial imperative aside, if a major am of undergxaduate leisure studies programs is to prepare students for careers, then what mechanisms exist to assist students with caree development and planning?

A review of current practices in Australian universities suggests that workplace skills are developed in a number of ways during the course of a student's undergraduate career. Skills (and knowledge) are developed though structured degree programs, employment (the majority of Australian students work part-time), work placements (in some applied degrees), involvement in the community, and through other life experiences. The degree to which such skills are developed in any systematic or planned way - or in relation to a clearly defined however, debatable.

Career centres in Australian universities have traditionally taken responsibility for student career development support. While university-based career services offer valuable resources to students by providing such things as resume-writing workshops, employment opportunity databases and career counselling services, the separation between these services and academic curricula (Ashenden \& Milligan, 1998) tends to reinforce an artifictal dichotomy between career and education. As the realities of academic and sociai pressures begin to dominate the lives of students, there is a tendency for career pianning to be left on the 'back-burner' As a result, most students who visit career-counselling services do so towards the end of their degree program, and often as an afterthought. Career counsellors are often frustrated by this post-hoc approach to career planning Graduates, in urn, often lament the fact that they had not availed themselves of career planning support 
services during theur undergraduate studies (Ashenden \& Milligan, 1998). Because career counsellors are generally onily able to reach students who choose to visit them. what role might academics play in ensuring that all students are aware of the importance of engaging in strategic career planning throughout their degrees?

\section{Portfolio careers and leisure studies graduates}

Students enrolling in leisure studies programs are faced with an overwheiming range of career options when they graduate. Unlike graduates from more structured applied degrees, such as social-work, medicine, law, nursing and teaching, where career paths are more clear cut (Arthur \& Rouseau, 1996), leisure-related careers are extremely eclectic and are often affected by changes in the economy and other external factors, such as seasonality and cuitural trends. This context of change is suited to the development of portfolio careers, where career pathways are not necessarily contingent upon the success of a specific organisation or profession. A portfolio career is strategically crafted by individuals, based on their perception of the capabilities and attributes they possess in reiation to changing work opportunities. Portfolio careerısts, according to Jackson et al. (1996: 26), 'seek strategic job moves and developmental experiences to compile marketable and refreshed skill profiles which keep pace with the rapid changes in roles and job demands'. Those interested in enhancing the employability of leisure studies graduates should, we would argue, consider how to prepare students for portfolio careers, given the eclectic and changeable nature of the field.

Centrai to the task of preparing students for portfolio careers is the establishment of mechanusms whereby students become proficient in recognizing their personal interests, goals, capabilities and skills and, in tum, how these attributes might be best used in the le1sure industries. In order to do this, students need to be given the opportunity to identify and monitor developments in the labour market throughout their degree program, while concurrently developing a career plan that is flexible and able to be modified to accommodate changes in career aspirations. Because leisure studies educators are best placed to advise on employment trends within the lessure industries, it seems logical that career planning and development strateges should be incorporated into lessure studies curricula. The following section outlines some key prunciples that might underpin such an approach.

\section{Career development for portfolio careers}

Any strategy designed to encourage students to understand and embrace the flexible and self-determining characterıstics of a portfolio career should be student-centred. Peters and Waterman (1982) argue that many traditional approaches to career planning are overly prescriptive and inflexible, primarily because too much emphasis is placed upon goal-setting driven by external cues without allowing room for expermentation and self-directed learnung. As an alternative, Peters and Waterman suggest a 'ready, fire, aim!' approach to career planning that allows individuals to experiment with a range of work experiences before committing to a particular career path. An ideal context for such experimentation is work experience placements that are often a required component of leisure studies programs in Australia. Indeed, students themselves recognise the vaiue of gaining experience prior to leaving higher education. In a survey of young people's attitudes to post-compuisory education work place experience was identified as the most useful source of information regarding career planning and development (Dept of Employment, Education and Training, 1994).

While it is apparent that work experiences may play an important role in the deveiopment of student career goais, there is a risk that career development will take place in a haphazard manner. Students who undertake workplace experiences as part of their degtee may do so based on the availability of placement opportunities rather than on a carefully planned and integrated strategy relating to personal career goals. Indeed, there have been many warnings that successful learning through experience does not necessarily happen automatically but is the result of a systematic and pedagogically sound framework (Jacoby \& Associates, 1996).

One attempt to provide a more strategic grounding to work expenence that is relevant to graduate employability is the 'service-learnung' model. Jacoby and Associates (1996) explain that, unlike traditional models of work experience, service learning is based upon reciprocity and reflection. Reciprocity refers to what is traditionally the central focus of work expenences in which students provide their labour and in return gain experience and skills associated with that experience. However, as Dewey (1938) has argued, experience will oniy translate into learnung if there is an opportunity to reflect upon that experience.

The process of reflection. includes both expenential reflection and selfreflection. Experiential reflection contains the processes of conceptual map reading and map making. Map reading involves students developing knowledge about particular context, while map making is more creative and allows for the process of generalising knowledge to other contexts (Lester 1999). Self-reflection, involves a mirroring process in which students examine how an experience relates to how they see themselves and how they would like to be seen (Brown \& McCartney 1999). These two components of reflection allow students to develop what migh best be described as a 'whole-life approach' to career deveiopment. Rather than just learning about what is unvolved in a particular career, students also learn about who they are in relation to that career. This is particularly important for a portfolio career where contexts change and a person's capabilities and sense of self become key reference points for career choices.

A whole-life approach to career development recognizes that the reflective process needs to be applied to more than just formally prescribed experiences. Students need to be encouraged to consider all facets of experience in relation to their career goals (Kezar \& Rhoads, 2001). Summer and part-tıme jobs, voluntary actıvities and short courses taken at adult education colleges can be as valuable for 
the purposes of reflection as more formally prescribed experiences such as work placements and internships. In addition to optumising opportunities for reflection this whole-life approach also optimises the opportunities for students to recognuse that many of the capabilities they develop through extra-curricular experiences are transferable to other contexts. This awareness is important for developing a 'wellrounded practitioner who can integrate all aspects of thear prior knowledge' (Codd, 1997 , p. 140).

\section{Student-centred capabilities}

Graduate capabilities are central to most discussions of employability (e.g. Evers et al., 1998; Holmes, 1999). Much of this discussion tends to focus on how to develop in students the capabilities which prospective employers will vaiue. However, given the diverse range of tasks and dutıes associated with the myriad jobs in the ietsure industries and services, it is impossible to identify one overarching set of relevant capabilities. Consistent with a whole-life approach to career development, Waterman (1991) argues that career pianning for a changing environment requires an organic approach that piaces a career within the context of life goals. Rather than focusing upon specific career-related skills that may become redundant or that require a commitment to a specific career path, Waterman suggests that it is wise to develop skills that are adaptable and transferable. This is consistent with a recent focus in higher education upon generic skills that promote lifelong tearnıng. (e.g. Butler, 1989; Candy, Crebert and O'Leary, 1994; Dept of Education, Trainung \& Youth Affairs, 1999; National Board of Employment Education and Trainung, 1995).

It has been argued that generic skills are deemed to be highly transferable and will help a graduate not only in their short-term career endeavours but aiso throughout life (Candy et ai., 1994). Skills and qualities which have been identified as 'generic' and are also referred to as 'core' and 'transferable' skills, include: the capacity to learn new skills and procedures; decision-making and problem-solving abilities; a capacity for critical thinking; effective communication and interpersonal skills; an ability to access information and utilise technology; professional integnty; tolerance; and ethical practıce (Butler, 1989; Evers et al., 1998). Recently, other areas of ability that have not previously appeared on lists of generic abilities in the literature are also worthy of consideration, for example 'emotıonal intelligence' (see Goleman, 1998).

In the past, many of these so-called 'generic' skills have been treated outside the curriculum. Students have been encouraged to develop them through on-the-job training or through enrolment in specialized workshops offered through university libranes or externally through avocational, therapeutic and/or recreational adult non-degree programs. However, in recent years unıversities have begun to recognize the umportance of generic skills in not only assisting students to learn in a university context, but also as a necessary asset for students embarking on careers (Dept of
Education, Training ad Youth Affairs, 1999). Indeed, the value of developing these generic skills among undergraduate students has been highlighted in surveys of graduates and employer groups (see Guthre, 1994; National Board of Employment graduates and employer groups (
Education and Trauning, 1995b).

Strategies for incorporating generic skills unto curriculum design in leisure studies have tended to be sporadic. The few discussions that have focused upon the inciusion of these skills focus primarily upon specific skill types that can be added to existing course designs (see Henderson \& Bedini, 1989; Patterson \& Pegg, 1999). While these efforts are commendable, such approaches tend to be $a d$ hoc and fail to give generic skills the attention they deserve. As a consequence, their acquisition is often treated as a 'poor cousin' to 'real knowledge' in curriculum design. Since Australian unversities are now being assessed on their ability to develop genenc skills in undergraduates, it is important to identify ways of incorporatung them into curriculum design more systematically and in ways that are relevant to student needs and aspirations.

Consistent with a whole-life approach to career development, Holmes (1999: 92) contends that the development of a checklist of capabilities is irrelevant to employability if students are unable to recognise how those capabilities relate to career and life goals that are centrai to their 'graduate identity'. Graduate identity refers to 'a dynamic relationship between the undividual's personal sense of self and the social processes which, to a stgnificant degree, determine what counts as the criteria for being ascribed a particular identity' (Holmes, 1999: 93). Students may well be able to demonstrate their proficiency in a list of capabilities that may be predetermuned by external forces, such as higher education administrators, employers or government agencies, but employability is more likely to be enhanced if students can identify, in a coherent way, how those capabilities relate to 'a sense of self', as reflected through their graduate identity, and use this to shape their careers.

\section{Providing evidence of capabilities}

Holmes (1999: 88) observes that, 'Traditionally, the reiationship between a program of study and employment has been based on an 'education-assessment-selection process'. This involves students undertaking a range of subjects that develop knowledge and skills deemed by gatekeepers, such as academics, professional bodies, accrediting agencies and employers, to be attributes appropriate to a particular career or field of study. Students are assessed on their knowledge and skills to determine whether they indeed possess such attributes. Assuming they pass the assessment, students graduate with a testamur mdicating the degree awarded and a transcript that lists the subjects taken and the grade attained for each subject These two official documents provide some tangible evidence of the range of skills and knowledge attained in relation to a field of study and/or profession. Graduates then apply for jobs using the testamur and transcript as evidence of their capabilities. Employers, in turn, make judgments about applicants and select 
graduates based on the relevance of graduate capabilities in relation to employment roles.

Clearly, the uni-dimensionality of this model fails to address the multidimensionai nature of a portfolio career. In order to enhance the development of a portfolio career, graduates need to provide a wider range of evidence of their capabilities and career goals and thelr relevance to the needs of industry.

Over the past decade 'career portfolios' have emerged as a tool for providing evidence that supports a graduate's clam to having particular capabilities. The shared nomenciature of portfolio career and career portfolio is more than coincidental. Developing a successful portfolio career requires an ability to recognize the relationship between career goais and particular capabilities that are relevant in the current and future labour market climate. A career portfolio is a tool for demonstrating that relationship.

Career portfolios have three main functions. First and foremost, they provide a coherent mechanism for linking knowledge and abilities to broader goals. Second, they provide evidence of graduate capabilities to prospective employers. Third, they offer a tool for reflection that allows individuais to monitor the relevance of their goals to current and changing curcumstances. In addition to these functions, the development of career portfolios offers unversities a tangible medium to demonstrate the professional relevance of curricula, as well as providing a means of monitoring student academic performance.

It has been suggested that at a minimum a career portfolio should contain a clearly defined introductory section that articulates specific career goals (Melograno, 1998) and copies of documents, typically categorized into sections that reflect an individual's curriculum vitae, inciuding university transcripts and certificates that demonstrate completion of particular courses. However, the more sophisticated and more compelling portfolios lead the reader through each document explainung what abilities it demonstrates. The contemporary career portfolio developed and made available as a web-page, provides a flexible tool that can be modified and tailored to address the interests of particular audiences, including specific employers (Hartnell-Young \& Morris, 1999). In summary, career portfolios offer a mechanism for demonstrating to future employers how, when and where partıcular attributes relevant to a specific position have been developed.

It is our belief that the inciusion of a systematic whole-life approach to career development in curricula is likely to enhance the employability of leisure studies graduates. The second part of the paper presents a case-study of how this approach was developed and umplemented in response to an external review of one leisure studies degree program. The approach laid out in the case-study is consistent with recommendations made by AUQA following an audit of the programs offered at the University of Newcastie in 2002. These included the development of strategies to make more clear the link between specific degree programs offered at the university, the employability of graduates and the needs of empioyers.

\section{A case-study of work integrated learning}

The provision of work-based expenence for students has always played an important role in the Bacheior of Social Science (Recreation and Tounsm) program at the University of Newcastie. In previous years, the main vehicle for work experience was 'Professional Development' - a compuisory subject that incorporated a 240 hour work placement offered in the third and final year of the degree. While this placement provided a valuable learning expenence for students, it had a number of shortcomungs that were highlighted in an externai review of the curriculum. In particular, it was apparent that many students had difficulty making connections between their placement and their future careers. In addition, it was recognized that a piacement in the final year of a degree provided limited opportumty for expertmentation with a range of work place experiences. As a result, a Work Integrated Learnıng (WIL) initiatıve was developed, incorporating a more strategic, studentcentred, whole-life approach to career development.

The objectives of WIL are to provide students with opportunities to:

- engage in a self-reflectrve process that focuses upon developing and modifying flexible career goals;

- engage in a range of work-place and extra-curricular experiences relevant to career and life interests

- reflect upon the relationship between concepts, principles and theories developed in the degree, and workpiace and extra-curncular experiences;

- identify, develop and demonstrate proficiency in generic and professional skills relevant to career goals; and

- develop an understanding of trends and issues within leisure industries and services that affect the labour market.

These objectives are addressed by students undertaking a senes of workplace and related expenences over the course of the three years of the degree, while also engaging in a range of reflectiye activities that link these and other, extra-curricular, experiences to individuai career and life goais. The vehicle used to incorporate WIL into the degree program is a suite of three compulsory professional preparation subjects that are taught over the course of the three-year degree. Each subject focuses upon specific professional capabilities associated with leisure management such as marketıng, customer service and human resource management, that provide an appropriate context for addressing career development issues.

During each year of the degree, students follow a process, illustrated in Figure 1 , that provides a structure for each WIL experience.

Each year, as part of the WIL program, stucients are assigned work that requires them to undertake an in-depth examunation of a particular sector of the labou market that is of interest to them (for example, sport, the arts, community recreation, tounsm, therapeutic recreation, outdoor recreation), identifying current issues and 
Figure 1: An Overview of a Work Integrated Learning Framework

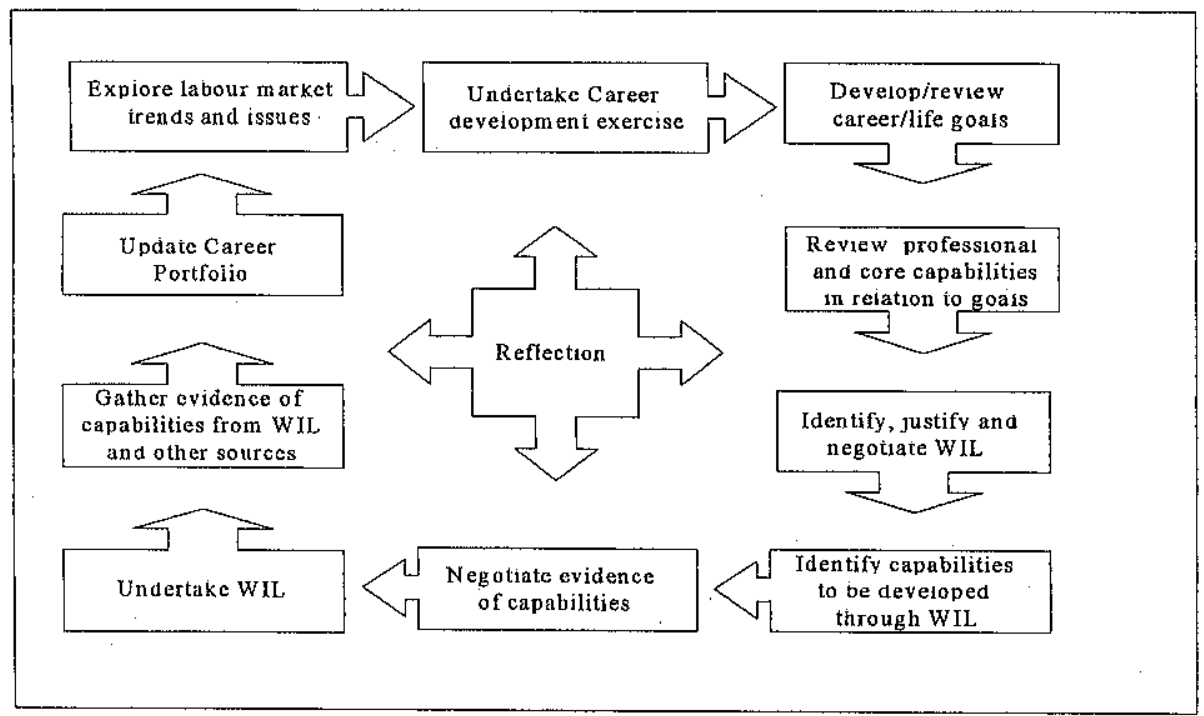

employment trends relevant to that sector. Students then participate in a series of workshops (conducted by academic staff in conjunction with staff from the university career counselling services unit) that address the skills and knowledge relevant to securing employment not only in specific sectors of the leisure industries but also across and outside these sectors. The focus of some of these workshops remains the same over the three years, for example, a career portfolio development workshop. Other workshops vary for each year of the degree, for example, in the first year students engage in self-exploration workshops that introduce a range of self-assessment tools, including aptitude and personality evaluations. In the second year of the degree workshops focus on job search techniques, including accessing relevant on-line employment databases. Workshops on job application and interview techniques are addressed in the third year of the degree.

As part of their preparation for each level of the WIL program, students are expected to identify and/or amend career-specific goals and objectives and to identify a range of professional and genenc capabilities necessary for achieving those goals. This process engages students in a reflective process involving examination of capabilities they feel they possess and consideration of what evidence they might produce to demonstrate those capabilities, urrespective of whether the evidence is based on work conducted as part of thelr degree program or is independent of degree requirements. Students also develop a 'deficit list' of capabilities they feel they lack, with a view to developing a strategy for developing those capabilities through a placement or program that will help them achieve their learnung goals. While a database of work placement opportunities is mantamed within the department, students are encouraged to seek out theur own placements. However, students do not necessarily have to select placements that follow traditional practicum experiences. In lieu of working in an external agency students may elect, if they wish, to undertake an evening class or a skills development course (for example, an advanced first-aid or computer software competency course), so Iong as this experience helps students to develop particular capabilities they have systematically and strategically identified as necessary for achieving their career and life goals.

Central to the WIL process is a range of reflective activities that connects student experiences to personal career and life goals. Throughout the semester students are asked to participate in on-line seminars that allow them to reflect upon their goals and to adjust them according to the knowledge they develop. through their placements. At the end of the semester students submit a report reflecting upon their WIL experience in terms of their career plans and the relevance of those plans to the current labour market. Students are aiso expected to develop and maintain a career portfolio that demonstrates a relationship between career goals and capabilities. At the completion of each WIL program, students are required to collect evidence of the capabilities they have developed and to add that evidence to their career portfolio. At the completion of the final WIL program in the third year of their degree, students are required to present their portfolio and are assessed on their ability to show evidence of progression toward a flexible yet coherent career plan.

\section{Conclusion}

While career centres have traditionally played a support role in assisting students with career development issues, the separation of these services from academic programs has tended to renforce an artificiai dichotomy between 'career' and 'education'. As a consequence, unuversities may not have been as effective as they might have been in enhancing the employability of their students. Given on-going changes in patterns of employment and the advent of portfolio careers, and given the eclectic nature of the ieisure services field, it is umportant that students be given the opportunity to add value to therr capabilities within the context of a systematic career plan.

The case-study described above presents an approach that was designed to enhance the employability of graduates from the Bachelor of Social Science (Recreation and Tourism) program at the University of Newcastie. This whole-life approach to employability focuses on the importance of demonstrable generic skills in the context of a portfolio career. Arguably the idea of a career portfolio has the potential to enhance graduates' empioyability throughout their career. In a rapidly changing field such as lessure management, those professtonals who are 'career conscious', are alert to the changing social and industrial environment and are 
constantiy considering how therr generic and specialist skills and experience might be extended and enhanced, are most likely to be well placed to take advantage of change and to make significant contributions to the field as professionals.

\section{References}

Arthur, M. B., \& Rousseau, D. M. (1996) The Boundaryless Career: a New Employment Principle for a New Organizational Era. New York, Oxford University Press.

Ashenden, D. \& Milligan, S. (1998) The Australian Good Untversities Guide: Australian Untversities - Course and Campuses in 1999. Subiaco, WA, D. Ashenden, \& S. Milligan.

Brown, R.B., \& McCartney, S. (1999) Multiple mirrors: reflecting on reflections. In D O'Reilly, L. Cunningham \& S. Lester (eds), Developing the Capable Practitioner: Professional Capability Through Higher Education. London, Kogan Page, pp. 16-32.

Buck, L.L., \& Barrick. K.R. (1987) They're trained, but are they employable? The Vocational Education Journal, 62(1), 29-32.

Butier, A. (1989) Lifelong Education Revistted, Austratia as a Learning Soctety. Melbourne, Commission for the Future.

Candy, P., Crebert, G., and O'Leary, J. (1994) Developing Lifelong Learners Through Undergraduate Education - Report to the National Board of Employment Education and Training. Canberra, AGPS.

Codd, J. (1997) Knowledge, qualifications and higher education: a critical view. In M Olssen \& K. Moms Matthews (eds), Education Policy in New Zealand: The 1990s and Beyond. Paimerston North, Dunmore Press, pp. 130-144.

Department of Employment, Education and Training (1994) Young People's Attitudes to Post-compulsory Education and Training: Follow-up Study. Canberra, AGPS.

Department of Education Training and Youth Affairs, (1998) Evaluatıons and Investig ations Programme Interim Report. Research on Employer Satisfactson with Graduate Skills. Canberra, AGPS.

Department of Education, Training and Youth Affairs (DETYA) (1999) The Quality of Australian Higher Education. Canberra, AGPS.

Dewey, J. (1938) Expenence and Educatton. New York, Collier Books.

Evers, F. T Rush, J. C., \& Bedrow, I. (1998) The Bases of Competence: Skills for Lifelong Learning and Employability. San Francisco, CA, Jossey-Bass.

Goieman, D. (1998) Working with Emotional Intelligence. London, Bloomsbury.

Griffith University (2001) Bachelor of Leisure Management website: www.gu.edu.au:80/ua/aa/ hbk/course/lst101_01.htm.

Guthrne, B. (1994) Graduate Labour Market Survey - Report to the Graduate Careers Council of Australia. Canberra, AGPS.

Handy, C. (1984) The Future of Work. Oxford, Basil Blackwell

Handy, C. (1996) Beyond Ceriainty: the Changing Worlds of Organizaiions. Boston, Harvard Business School Press.

Hartnell-Young, E. \& Morris, M. (1999) Digital Professtonal Portfolios for Change. Cheitenham, Vic., Hawker Browniow Education.

Henderson, K. A., \& Bedini, L. A. (1989) Teaching ethics and social responsibility in leisure studies curricula. Schole, 4(1), 1-14.
Holmes, L. (1999) Competence and capability: from 'confidence trick' to the construction of the graduate identity. In D. O'Reilly, L. Cunnungham, \& S. Lester (eds.), DevelopIng the Capable Practitioner: Professtonal Capability Through Higher Educailon London, Kogan Page, pp. pp. 83-98.

Jacoby, B. \& Associates, (1996) Service-learning in Higher Education: Concepts and Practices. San Francisco, CA. Jossey Bass.

Jackson, C., Arnold, J., Nichoison, N. and Watts, A. (1996) Managing Careers in 2000 and Beyond. Brighton, Institute for Employment Studies.

Johnson (1998) Course Expertence Questionnaire: A Report Prepared for the Graduate Careers Council of Australia. Parkville, Vic., Graduate Careers Council of Australia.

Kezar, A. \& Rhoads, R. A. (2001) The dynamic tensions of service iearnung in higher education. Journal of Higher Education, 72(2), 148-72.

Lester, S. (1999) From map-reader to map-maker: approaches to moving beyond knowledge and competence. In D. O'Reilly, L. Cunningham, and S. Lester (eds.), Developing the Capable Practitioner: Professional Capability Through Higher Education. London, Kogan Page, pp. 165-87.

Lynch, R. \& Jonson, P. (1999) A chronology of Australian courses in recreation and leisure studies. Annals of Leisure Research. 2, 120-29.

Melograno, V. (1998) Professional and Studeni Portfolios for Phystcal Educatton. Champaign, IL: Human Kinetics.

National Board of Employment, Education and Training (1995a) Demand for and Dimensions of Education and Training. Canberra, AGPS

National Board of Employment, Education and Training (1995b) Converging Technology, Work and Learning. Canberra, AGPS.

Patterson, I. \& Pegg, S. (1999) Adult learning on the increase: the need for leisure studies programs to respond accordingly. Journal of Physical Education, Recreation \& Dance, $70(5), 45-50$.

Peters, T.J. \& Waterman, R.H. (1982) In Search of Excellence: Lessons from Amertca's Best-run Compantes. New York, Harper \& Row.

University of Newcastle (2001) Bacheior of Social Science (Recreation and Tourism), website: www.newcastle.edu.au/department/lt/structre.htm.

University of Technology Sydney (2001) Bachelor of Arts in Leisure Management, website: www.uts.edu.au/div/publications/bus/ug/bl10.htmi.

Waterman, J. A. (1991) Career and life planning: a personal gyroscope of change. In J. M. Kummerow (ed.), New Directions in Career Planning and the Workplace: Practical Strategies for Counsellors. Pailo Alto, CA, Consulting Psychologists Press, Inc., pp.
$27-40$. 